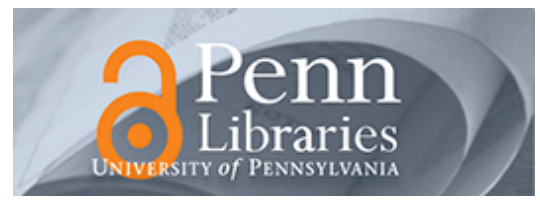

University of Pennsylvania

ScholarlyCommons

Management Papers

Wharton Faculty Research

3-25-2013

\title{
Swept Away by the Crowd? Crowdfunding, Venture Capital, and the Selection of Entrepreneurs
}

Ethan Mollick

University of Pennsylvania

Follow this and additional works at: https://repository.upenn.edu/mgmt_papers

Part of the Management Sciences and Quantitative Methods Commons

\section{Recommended Citation}

Mollick, E. (2013). Swept Away by the Crowd? Crowdfunding, Venture Capital, and the Selection of Entrepreneurs. SSRN's eLibrary, Retrieved from https://repository.upenn.edu/mgmt_papers/263

This paper is posted at ScholarlyCommons. https://repository.upenn.edu/mgmt_papers/263

For more information, please contact repository@pobox.upenn.edu. 


\title{
Swept Away by the Crowd? Crowdfunding, Venture Capital, and the Selection of Entrepreneurs
}

\author{
Abstract \\ Venture Capitalists (VCs) are experts in assessing the quality of entrepreneurial ventures. A long tradition \\ of research has examined the signals of quality that VCs look for in new ventures, and the biases that \\ result from the VC selection process. Recently, an alternative form of new venture funding has arisen in \\ the form of crowdfunding, which relies on the judgement of millions of amateurs about which \\ entrepreneurial projects are worth funding. Little is known about the degree to which amateurs respond to \\ the same signals of quality as VCs, and whether they are subject to the same biases. To address this gap, \\ I examine 2,101 crowdfunded projects that match characteristics of more traditional VC-backed seed \\ ventures. Despite the radical differences in selection environments, I find that entrepreneurial quality is \\ assessed in similar ways by both VCs and crowdfunders, but that crowdfunding alleviates some of \\ geographic and gender biases associated with the way that VCs look for signals of quality.
}

\section{Keywords}

crowdfunding, entrepreneurship, venture capital, community, new venture

\section{Disciplines}

Management Sciences and Quantitative Methods 


\title{
Swept Away by the Crowd?
}

\section{Crowdfunding, Venture Capital, and the Selection of Entrepreneurs}

This paper is an early draft, not for citation. It is certain to be changed or modified.

\author{
Ethan Mollick \\ The Wharton School of the University of Pennsylvania \\ emollick@wharton.upenn.edu
}

\begin{abstract}
Venture Capitalists (VCs) are experts in assessing the quality of entrepreneurial ventures. A long tradition of research has examined the signals of quality that VCs look for in new ventures, and the biases that result from the $\mathrm{VC}$ selection process. Recently, an alternative form of new venture funding has arisen in the form of crowdfunding, which relies on the judgement of millions of amateurs about which entrepreneurial projects are worth funding. Little is known about the degree to which amateurs respond to the same signals of quality as VCs, and whether they are subject to the same biases. To address this, I examine 2,101 crowdfunded projects that match characteristics of more traditional VC-backed seed ventures. Despite the radical differences in selection environments, I find that entrepreneurial quality is assessed in similar ways by both VCs and crowdfunders, but that crowdfunding alleviates some of geographic and gender biases associated with the way that VCs look for signals of quality.
\end{abstract}

I would like to thank Jeanne Pi, Stacy Cowley, David Goldman, Julianne Pepitone, Olivia Smith, and Laurie Segall for their help providing data. I also would like to acknowledge the help of Alex Kefalos, Elizabeth Weiss, and Xiang Ao for their help with the analysis and coding of data. Thanks also to the Wharton Junior Faculty Workshop, the Wharton Organization Theory Workshop, and Utah-BYU Strategy Conference for feedback. Any errors in the paper are my own. 


\section{Swept Away by the Crowd? Crowdfunding, Venture Capital, and the Selection of Entrepreneurs}

Venture capitalists (VCs) are frequently required to assess the quality of early stage entrepreneurial ventures, a process that is fraught with uncertainty. Without access performance data or even working products, venture capitalists have developed an expertise in using what limited signals are available to determine whether a new enterprise may be capable of achieving its goals (Kortum \& Lerner, 2000; Lerner, 2002; Ueda, 2004). The expert judgment of VCs about the quality of companies are highly consequential to the survival of new ventures, since VCs provide both investment and important connections to other resources (Baum \& Silverman, 2004; Ferrary \& Granovetter, 2009). Very recently, however, an alternative funding system for new ventures has emerged in the form of crowdfunding. Rather than relying on expert opinions, crowdfunding allows millions of individuals to make decisions about which entrepreneurial projects they wish to back. Though the amateurs and the experts differ in many key ways, they are ultimately assessing whether early stage entrepreneurial ventures have the ability to succeed at their goals by looking for signals of quality. While the rise of amateur communities and crowds has been widely discussed (Bagozzi \& Dholakia, 2006; Jeppesen \& Frederiksen, 2006; Lee \& Cole, 2003; Mannes, 2009), there is no clear evidence on whether they would approach signals of venture quality in the same way as experts, or with the same consequences. Indeed, given the differences in incentives, experience, and training, amateur communities may have very different approaches to judging project quality. Using a unique 
dataset of crowdfunding efforts, I seek to shed light on the approaches of experts in assessing entrepreneurial quality by comparing their funding selection process to the role of amateurs.

The process by which expert VCs assess new ventures has long been of interest to scholars (Amit, Brander, \& Zott, 1998; Franke \& Gruber, 2008; Gompers \& Kovner, 2006; Higgins, Stephan, \& Thursby, 2011; Kirsch, Goldfarb, \& Gera, 2009; Shane \& Cable, 2002), who have also noted the gender and geographic biases that distort VC assessments (Greene \& Brush, 2001; Harrison \& Mason, 2007; Stuart \& Sorenson, 2003a). By contrast, very little is known about crowdfunding, and, indeed about funding regimes outside of the traditional VC environment (Harrison \& Mason, 2007; Schwienbacher \& Larralde, 2010). Though both expert VCs and amateur crowdfunders provide seed funding to new ventures, there is no reason to expect that crowdfunding backers and professional venture capitalists use the same selection criteria in choosing ventures to fund. I use this contrast to examine the signals to which amateurs and experts respond, and the consequences of these choices on the demographics of funded entrepreneurs. Despite the radical differences in selection environments, I find that entrepreneurial quality is assessed in similar ways by both VCs and crowdfunders, but that crowdfunding alleviates some of geographic and gender biases associated with the way that VCs look for signals of quality. 


\section{Theory and Context}

\subsection{Venture Capital and Entrepreneurial Selection}

Technology entrepreneurship is a critical engine of both technical change and disruptive innovation (Schumpeter, 1942). For at least a quarter century, technology entrepreneurship has been largely been defined by the Silicon Valley model (Kenney \& Burg, 1999; Saxenian, 1996). In that model, venture capital firms serve as a key actor, and are often considered to be the most important actors in the system outside of the entrepreneurs themselves (Ferrary \& Granovetter, 2009; Kenney \& Burg, 1999). VC has held this critical position in the institutional environment of technology entrepreneurship since at least the 1970s, and, though the industry has expanded and contracted several times since then, the nature of venture capital itself has been fairly stable (Gompers \& Lerner, 2001, 2004).

Because of the importance of venture capital, the process by which VC is allocated has been studied extensively. The "venture capital cycle" (Gompers \& Lerner, 2004) begins when venture capitalists locate firms of interest, primarily through network connections and direct contact with entrepreneurs. Out of this population, venture capitalists select firms for financial investment based on expected return and fit with an existing portfolio (Amit et al., 1998; Baum \& Silverman, 2004; Gompers \& Lerner, 2004; Shane \& Venkataraman, 2003). After this initial investment, the venture capital firm then plays an active role in shaping the portfolio firms, granting them reputational effects from VC endorsement (Hsu, 2004; Stuart, Hoang, \& Hybels, 1999); providing monitoring and governance (Gompers \& Lerner, 2004; Lerner, 2012); and providing access additional resources for the 
firm (Baum \& Silverman, 2004; Ferrary \& Granovetter, 2009). Since VC firms sit at the center of so many networks of influence, they fulfill a critical role in the innovation process of high technology ventures (Ferrary \& Granovetter, 2009).

Of these many roles for $\mathrm{VC}$ in the technology entrepreneurship system, one of the most critical is selection. Venture capitalists, by choosing which firms to provide with resources, help determine which entrepreneurs, and ultimately which technologies, will succeed. Evidence suggests that venture capitalists are quite efficient at the selection of promising technological opportunities relative to other sorts of corporate entities (Kortum \& Lerner, 2000; Lerner, 2002; Ueda, 2004). However, venture capital decisions are often made on relatively little data, and are subject to cognitive biases and limitations on knowledge (Baum \& Silverman, 2004; Ferrary \& Granovetter, 2009). This makes selection an especially important interaction between venture capitalists and technology entrepreneurs.

The venture capital selection process has been studied by many scholars (Baum \& Silverman, 2004; Dushnitsky, 2009; Kirsch et al., 2009; MacMillan, 1986; Stuart \& Shane, 2002). Researchers have found that since technology entrepreneurship is inherently uncertain, investors often need to act on partial information about particular ventures. Particularly important in the selection process, given the often diffuse and unreliable data that surrounds new ventures, are potential signals of quality (Michael, 1974). These signals can include endorsements from trusted third parties, the backgrounds of founders, and the degree of preparation and care that goes into the pitches made by entrepreneurs (Beckman, Burton, \& O’Reilly, 2007; Kirsch et al., 2009; Phillips, 2002; Sørensen \& Fassiotto, 2011). The expert VC selection process is often highly personal in nature, with these signals communicated 
during face-to-face meetings, shared activities (such as group cycling), and the extensive use of shared network connections (Fiet, 1995; Hisrich \& Jankowicz, 1990; Williams \& KOMISAR, 2005).

Of the critical signals identified by expert VC investors, scholars have found that venture capitalists seem to be particularly attentive to the quality of the startup team in making decisions about whether to invest in a particular venture (Franke \& Gruber, 2008; Fried \& Hisrich, 1994; Shepherd, 1999). In particular, given the variability in individual ability (Mollick, 2012), the backgrounds and past successes of founders is used as a signal of potential future success (Franke \& Gruber, 2008; Sørensen, Burton, \& Beckman, 2002). VCs have come to believe that past performance is the best indicator of future performance, and thus are more likely to fund organizations that spin off from prominent firms or successful projects (Beckman et al., 2007; Chatterji, 2008).

Signals of quality can come not just from the startup teams themselves, but also based on social network connections. A number of scholars have demonstrated that endorsements and alliances with prominent third parties can assist startups in gaining access to resources (Baum, Calabrese, \& Silverman, 2000; Baum \& Oliver, 1996; Stuart et al., 1999), and that venture capitalists look for these endorsements when making funding decisions (Baum \& Silverman, 2004). These endorsements are important not just because they represent critical sources of resources for firms (as in the case of alliances), but also because they serve as reputational signals, especially where high status organizations are willing to use their prominence to back a new venture (Baum et al., 2000; Shane \& Cable, 2002; Stuart et al., 1999). 
Though much of the selection process relies on the reputation and demonstrated ability of entrepreneurs, expert VCs also judge the degree to which entrepreneurs are prepared to exploit the opportunity they have identified (X. Chen, Yao, \& Kotha, 2009). While research has been divided on the importance of business plans in general (Delmar \& Shane, 2003; Foo, Wong, \& Ong, 2005; Honig \& Karlsson, 2004), business planning does seem to indicate a level of preparedness that is associated with successful selection by VCs and angel investors (Cardon, Sudek, \& Mitteness, 2009; X. Chen et al., 2009). Venture capitalists look for preparation as a signal that entrepreneurs understand the risks and pitfalls of a new business, and have an approach to address some of these concerns.

While team background, endorsements, and demonstrated preparation all serve as important signals that a new venture is more likely to succeed (Michael, 1974; Shepherd, 1999), the fact that these assessments require both common networks and face-to-face interactions introduces biases into the VC process as well. The biases stem from limitations on how VCs gather signals, and they are without clear justification in performance.

One particularly well-studied bias is geographic. Venture capital investments are highly concentrated in just a few areas, where both entrepreneurs and venture capital firms are located $(\mathrm{H}$. Chen, Gompers, Kovner, \& Lerner, 2009; Kenney \& Burg, 1999; Owen-Smith \& Powell, 2004; Shane \& Cable, 2002; Stuart \& Sorenson, 2003b, 2008). There are many reasons for this clustering, including the benefits of spillover and talented pools of successful entrepreneurs (Feldman, 2001; Kenney \& Burg, 1999; Owen-Smith \& Powell, 2004), but at least some of the reason why VC selection is limited is due to limitations on VC networks and the requirement of face-to-face interaction. Specifically, VCs 
prefer to have direct access to and oversight of portfolio firms, and such monitoring is significantly easier when firms are within a driving distance of the office of the VC (H. Chen et al., 2009). Along these lines, Sorenson and Stuart (2005), find that the average distance between a lead VC and their investment is 70 miles.

A second set of biases is related to the gender of entrepreneurs: though women make up over $40 \%$ of all business owners in the US, less than $6 \%$ of venture capital funding has historically gone to companies with female CEOs, and only $1.3 \%$ of VC-backed companies have female founders (Canning, Haque, \& Wang, 2012; Greene \& Hart, 2003; Harrison \& Mason, 2007; Stuart \& Sorenson, 2008). Further, only $14 \%$ of all venture capitalists are women, and many female entrepreneurs believe that there are strong gender biases in VC funding (Miller, 2010). These biases may be due to gender prejudices. However, scholars have also suggested that an alternate cause of these biases are homophily, as male entrepreneurs are more likely to be selected by male venture capitalists based on shared networks and social preferences (Ruef, Aldrich, \& Carter, 2003; Stuart \& Sorenson, 2008).

Thus, while venture capitalists may successful use signals to identify potentially successful startups, the methods they use to identify these signals introduce gender and geographic biases. For entrepreneurs, therefore, successfully receiving a positive expert review - and the resources that result - has required founders to have the right backgrounds, network ties, and signals of preparation. It has also pushed founders towards male-dominated teams, and helped increase agglomeration. A new alternative approach to funding, however, has been developed in the form of crowdfunding.

\subsection{Crowdfunding}


Crowdfunding is a novel method for funding a variety of new ventures, allowing individual founders of for-profit, cultural, or social projects to request funding from many individuals, often in return for future products or equity. Crowdfunding projects can range greatly in both goal and magnitude, from small artistic projects to entrepreneurs seeking millions of dollars in seed capital as an alternative to traditional venture capital investment (Schwienbacher \& Larralde, 2010). With billions of dollars invested in this manner (Espositi, 2012), and large-scale action by the US Congress to encourage crowdfunding as a source of capital for new ventures, crowdfunding offers a potential alternative to the traditional models by which early-stage startups receive funding, including venture capital. Yet crowdfunding remains relatively unstudied (though see Kuppuswamy \& Bayus, 2013), outside of the still-uncommon analysis of particular crowdfunding efforts (Agrawal, Catalini, \& Goldfarb, 2010; Burtch, Ghose, \& Wattal, 2011).

Crowdfunding refers to a variety of different efforts by entrepreneurs - cultural, social, and for-profit - to fund their efforts by drawing on relatively small contributions from a relatively large number of individuals using the internet, without standard financial intermediaries. In one of the few published overviews of the topic, Schwienbacher \& Larralde (2010) define crowdfunding as "an open call, essentially through the Internet, for the provision of financial resources either in form of donation or in exchange for some form of reward and/or voting rights in order to support initiatives for specific purposes". Crowdfunding draws inspiration from concepts like micro-finance (Morduch, 1999) and crowd sourcing (Poetz \& Schreier, 2012), but represents its own unique category of fundraising, facilitated by dozens of internet sites devoted to the topic. 
Crowdfunding embraces a wide range of potential funding needs. Many crowdfunded projects seek to raise small amounts of capital, often under $\$ 1,000$, to initiate a particular one-time project (an event, for example). In these cases, capital is often provided by friends and family, and crowdfunding is simply a mechanism for gathering funds. Increasingly, however, crowdfunding appears to be a viable source for entrepreneurial seed capital (Schwienbacher \& Larralde, 2010), allowing entrepreneurs to raise the initial money required to start their new venture (Evans \& Leighton, 1989). For example, of the fifty highest funded projects on Kickstarter, the premier crowdfunding site, 45 have turned into ongoing entrepreneurial firms.

Crucially, crowdfunding offers a method of funding entrepreneurial ventures that differs in almost all aspects from venture capital funding. First, rather than being oligopolistic, it is democratic - over two million people have funded projects on Kickstarter alone. Second, as opposed to the tightlyknit VC community, crowdfunding backers are loosely organized, if at all. Third, compared to the closed networks of Silicon Valley, in crowdfunding almost all communication between those seeking funding and potential backers occurs in open, online communities. Fourth, crowdfunding in its current form involves no equity or monitoring rights ${ }^{1}$; backers have little to no further influence over organizations they backed, and gain no return other than the potential of a future product.

The process of crowdfunding is also very different than fundraising through venture capital. Individuals seeking funding publically list their projects, along with a fundraising window, and their

\footnotetext{
${ }^{1}$ The data collected is from a period where crowdfunding where no equity investment is permitted, though the US Congress has authorized equity crowdfunding (JOBS Act, $112^{\text {th }}$ Congress),
} 
desired capital raise (called a goal in crowdfunding). This public information also includes a description of what they hope to accomplish with the money, rewards they offer in return for funding, and any other material they hope will make the case for their efforts, including videos and pictures of prototypes. The project initiator then tries to promote their project, using social networks, media, influential individuals, and other means. The goal is to attract individual backers, or funders, that will pledge to support the project if the fundraising goal is met. There is often a substantial dialogue that develops between project proposers and potential backers, as comments, questions, and discussions take place on both the crowdfunding website, as well as external venues such as Twitter and Facebook. If the project achieves its goal, the money is transfer to the proposer, who has no legal obligation to the backers to complete the project, though, in practice, almost all projects make a serious effort at achieving their goals (Mollick, 2013).

A relatively small proportion of individuals seeking crowdfunding are technology entrepreneurs, as crowdfunding is increasingly popular in the arts and other fields (in 2012, $10 \%$ of Sundance films were crowdfunded (Dvorkin, 2013)). However, crowdfunded technology entrepreneurs have proven to be extremely innovative. According to industry experts, many of the most important projects in consumer electronics as of 2013 are funded by crowdfunds, including novel 3-D printers, electronic watches, video game consoles, and computer hardware (Jeffries, 2013). Further, some of the most successful crowdfunded projects were turned down by venture capitalists, before successfully raising funding from sites such as Kickstarter (Jeffries, 2013). Crowdfunding is likely to continue to evolve, but in the context of the collected data, during the time analyzed, crowdfunding is viewed as an important and viable source for raising funds for innovative technology startups. 
The selection of projects for crowdfunding offers an alternative selection environment to the VC-centric expert that prevails in technology entrepreneurship. There is no reason to suspect that the way that crowds select fundable projects would be the same as the way that VCs evaluate them. In every key variable, from expected outcomes to knowledge stocks, crowdfunding backers differ from VCs. This, then, provides an opportunity to compare expert versus crowd assessments.

\section{Crowdfunding and the Selection of Entrepreneurs}

The nature of crowdfunding implies a different role for individuals from those "crowds" studied by scholars interested in crowdsourcing (Poetz \& Schreier, 2012), prediction markets (M. Chen, 2008; Ray, 2006), innovation tournaments (Boudreau, Lacetera, \& Lakhani, 2010; Terwiesch \& Ulrich, 2009), and collective and group innovation (Jeppesen \& Frederiksen, 2006; O'Mahony, 2003). In most studies involving crowds, a market or selection mechanism exists to aggregate the output of the crowd and select the most appropriate outcome - whether an innovation, a price, or a product -- from out of many possibilities. Crowdfunding, however, relies on a large number of amateur investors making individual decisions. While the success or failure of a particular project may be influenced by the degree of investment already made (Kuppuswamy \& Bayus, 2013), investment decisions are individual, not collective. There is no price-setting mechanism, tournament, or selection process that aggregates crowd preferences. Thus, the crowd in crowdfunding can be thought of as a collection of fairly independent amateurs.

Due to the novelty of the phenomenon, there are no established signals that have been identified in among amateur funders, like those who perform crowdfunding (Schwienbacher \& Larralde, 
2010). Therefore, if crowdfunding responds to known quality signals in the same way as venture capitalists, it reinforces both the validity of these factors in predicting the performance of entrepreneurial ventures, and the ability of crowdfunding to select appropriate ventures to back. If, on the other hand, the quality signals used by VCs are not predictive of success in crowdfunding, it suggests that either crowdfunding does not properly assess project quality, or that the signals sought by VCs are ceremonial in nature (Kirsch et al., 2009) and are not generally predictive of entrepreneurial success. Under the assumption that these signals of quality are useful in assessing the potential viability of new ventures, however, crowdfunding backers should be evaluating new ventures according to the same criteria as VCs.

First, we know that VCs look at evidence of past success as a strong signal of the future outcomes (Beckman et al., 2007; Franke \& Gruber, 2008; Sørensen et al., 2002). It is not necessarily a given that crowdfunding would work the same way. However, given the diminished nature of identity online, it is not clear that potential investors would view background as being of as much important. More importantly, there is an emphasis on being a "misfit" in amateur online cultures that tends to privilege authenticity and informal connections over conventional establishment ties (Clay, 2012; Mollick, 2005). However, I would argue that history would provide credibility even to amateurs, as teams with a demonstrable history of success are viewed as more likely to deliver results, and therefore more likely to receive funding. The logic for venture capital and crowdfunding should be the same in this case, leading to $\mathrm{H} 1$ :

H1: Entrepreneurs who demonstrate a history of successful projects are more likely to be crowdfunded. 
A related issue is that of endorsements, which play an important role in $\mathrm{VC}$ decision-making (Shane \& Cable, 2002; Stuart et al., 1999). For venture capitalists, endorsements occur through network ties to prominent entities, and serve as signals of quality. Whether endorsements ultimately play a similar role in crowdfunding is less clear. Since they do not occur through trusted social networks, endorsements in a crowdfunding setting do not have the exchange characteristics of endorsements through personal networks, where reciprocity is possible (Brass, Galaskiewicz, Greve, Tsai, \& Anonymous, 2004; Stuart \& Sorenson, 2005). Endorsements may be thus viewed more cynically in the crowdfunding context. Even in this diminished state, however, endorsements should still play a role in providing signals of quality in crowdfunding, leading to $\mathrm{H} 2$ :

H2: Entrepreneurs who demonstrate third-party endorsements are more likely to be crowdfunded

The signal where the difference between $\mathrm{VC}$ and amateur views is likely to be largest is preparedness. Venture capitalists look for preparedness as a quality signal (Cardon et al., 2009; X. Chen et al., 2009). In crowdfunding, passion may trump preparedness, as many observers believe that crowdfunding backers look more towards surface details than the ability of entrepreneurs to execute (Bogost, 2012). Research that demonstrates that most crowdfunding projects deliver late further suggests that preparedness, especially in the form of working prototypes and demonstrated products, may be less clearly emphasized (Mollick, 2013). Nevertheless, I would expect that crowdfunders, like VCs, ultimately act to rationally assess the quality of projects, of which preparation is a key indicator.

H3: Entrepreneurs who demonstrate preparedness are more likely to be crowdfunded 
Though VCs and crowdfunders may, as hypothesized, agree on the signals that indicate entrepreneurial quality, they likely do so in very different ways. Due to the need for in-person evaluation and monitoring, venture capital investments are highly concentrated in just a few areas, where both entrepreneurs and venture capital firms are located (H. Chen et al., 2009; Kenney \& Burg, 1999; Owen-Smith \& Powell, 2004; Shane \& Cable, 2002; Stuart \& Sorenson, 2003b, 2008). Agrawal, Catalini and Goldfarb (2010), have argued, however, that crowdfunding need not be subject to the same geographic constraints as in VC investment. In their study of crowdfunding in the recording industry, they find that backers are much more widely geographically distributed, though backer distance is constrained by the social networks of the musicians seeking funding (Agrawal et al., 2010). This wider funder distribution relaxes a geographic constraint on where funding comes from, but it does not directly address the geographic distribution of successful projects themselves. Here, we might expect to see a similar effect. If monitoring is less of an issue, and backers are willing to fund projects outside of their local areas, then successfully funded entrepreneurs themselves might be more widely and democratically distributed in crowdfunding than in VC selection.

H4: Selected projects are less geographically concentrated in crowdfunding than in venture capital.

An extremely small percentage, between $1 \%$ and $6 \%$, of $\mathrm{VC}$ backed companies have female founders (Canning et al., 2012; Greene \& Hart, 2003; Harrison \& Mason, 2007). This gender bias may be due to in-network homophily (Stuart \& Sorenson, 2008), outright misogyny (Holmquist \& Carter, 2009), or a mix of these factors. In any case, these biases should not be as evident in crowdfunding. First, female backers may be more common in crowdfunding than in venture capital. Even if they are 
not, however, female backers should be able to more easily identify and select projects by female entrepreneurs, creating more efficient matching than occurs in venture capital. Additionally, gender should be less salient in the decision-making criteria of crowdfunding backers, since the process of backing in crowdfunding requires less face-to-face contact, and potentially less use of direct social networks.

H5: Gender is less predictive of selection in crowdfunding than venture capital.

Thus, I seek to test two sets of hypotheses. I expect that crowdfunding will respond to the same sets of signals of quality as venture capitalists. However, I argue that crowdfunding will relax some of the biases of venture capital, providing for wider access to key resources for entrepreneurs.

\section{Data and Variables}

To test these hypotheses, I used data extracted from Kickstarter, the largest crowdfunding site, which raised a total of $\$ 319 \mathrm{M}$ from $2.2 \mathrm{M}$ backers in 2012. Kickstarter supports crowdfunding in a wide range of areas, including film and the arts. For this study, however, we are interested in the use of Kickstarter in high technology entrepreneurship, and specifically as a source of potential seed capital. I thus limited the sample to only projects in the hardware, software, video games, and product design spaces - a total of 3,200 projects (less than $10 \%$ of the total projects on Kickstarter). Hardware, software, video games, and product design are all areas of VC investment, and areas where Kickstarter is viewed as an alternative strategy to venture capital investment (Jeffries, 2013). I further limited the projects to include only those looking for a $\$ 5,000$ or more in capital, to further focus on projects 
looking for more substantial funding ${ }^{2}$. Additionally, since Kickstarter requires its funders to be US residents, with US addresses and credit cards, I eliminated foreign Kickstarter projects, which, although they were started by US residents, were likely atypical compared to vast majority of projects inside the United States.

The result was 2,101 projects put forth by technology entrepreneurs looking for seed funding through Kickstarter between March 2009 and July 2012. While the data gathered on Kickstarter is of high quality, comparison of my data with count of projects at Kickstarter indicates that up to $10 \%$ of the failed projects may be missing from my dataset, though my data should have all of the successful projects. Based on comparisons of the data, these missing projects seem to only consist of those seeking less than $\$ 5,000$, and thus would not be part of the sample, but the nature of any gap cannot be precisely determined, and thus this is a potential limitation.

For each project, substantial data was gathered from the Kickstarter site itself, which provides a large amount of information on each project, including information about the entrepreneur, their plans, and their goals (See Figure 1). Kickstarter follows an "all or nothing" model, so funders' pledge money is only collected if the goal is reached. While other crowdfunding efforts do not always follow this model, it is currently the dominant approach to crowdfunding, and parallels the way that other funding efforts for new ventures work. Of the 2,101 projects, 592 (28\%) successfully achieved their funding goals and were funded. Projects are only funded when they reach their goals, so projects that failed

\footnotetext{
${ }^{2}$ As discussed in the results section, findings are also robust for goals of $\$ 100,000$ and above.
} 
to raise sufficient money received no funds at all. Successful projects in the sample received over $\$ 58 \mathrm{M}$ from 806,538 backers $^{3}$, with an average contribution per backer of $\$ 72$.

Two research assistants were used to code the degree to which projects demonstrated outside endorsements (such as media quotes), provided evidence of prototypes or early versions of projects, and invoked past successful projects or employers by name. The raters agreed in the vast majority of cases (88\% agreement on endorsement, $91 \%$ on prototypes, and $81 \%$ on the use of past project names). Kappa was substantial with regards to project names $(\varkappa=.57)$ and endorsements $(\varkappa=.52)$, and moderate on prototypes $(\varkappa=.45)$ (Munoz \& Bangdiwala, 1997). Though the models proved robust regardless of which RA ratings were used, for the tables herein I used the union of the two ratings. That is, if one RA felt there was an endorsement, and another RA did not, I coded that as an endorsement. This is because the signals of quality in crowdfunding result from the perception of an untrained group of investors - if at least part of the group of investors saw a signal as present, they would be expected to act as if the signal was identified. The RAs also coded the gender of the entrepreneurial team, as to whether it was mixed gender, all male, or all female ( $72 \%$ of the sample was all male, $7 \%$ all female, $8 \%$ mixed, and the rest unclear).

Further, in order to examine the role of geography in crowdfunding, I used two STATA programs, Nearstat (Jeanty, 2010) and Geocode (Ozmeck \& Miles, 2011) to generate geographic information on the locations of individual founders based on their location description. I mapped individual projects

\footnotetext{
${ }^{3}$ The 806,538 backers are not necessarily unique backers, as some backers may support multiple projects. The largest project had 87,142 unique backers
} 
to the closest micro or macro statistical areas, except that, where individuals were mapped to a micro statistical area, and were living within 20 miles of a larger metropolitan statistical area, I assigned them to the greater metropolitan area instead. To examine the role of social networks, I also take advantage of the fact that $47 \%$ of founders have linked their Facebook accounts to Kickstarter. This provides a control for the size of a founder's social network.

Additionally, a number of key variables were extracted from the Kickstarter data to use as controls, including the goal size, the length of the project, the duration of the fundraising period (usually either 30 or 60 days), the project category, and whether the project was featured on the front page of Kickstarter. I also control for rewards. Many projects offer rewards to funders, depending on the level of funds they pledge. These can range from credits in film or art projects to large-scale rewards, such as the ability to direct or influence projects. A common category of rewards are the products being developed by the founders, in which case Kickstarter can act as a "pre-order" system for concepts. Rewards levels are the number of reward tiers offered to funders, typically these would start relatively small, with an acknowledgement or formal thanks, and escalate to larger rewards, including on-site visits or special versions of products. A summary of the data can be found in Table 1, and a correlation matrix in Table 2 .

[Insert Table 1 Here]

[Insert Table 2 Here]

Hypotheses 4 and 5 require a comparison between VC selection and crowdfunding selection. To test H4, whether geographic distribution in crowdfunding is less concentrated than VC funding, I 
needed a comparison between crowdfunding and venture capital. I used VentureExpert to identify all seed-level VC funding rounds in high technology (excluding biotechnology) from March 2009 through July 2012 in the United States. A total of 835 deals, totaling $\$ 2.7 \mathrm{~B}$, were found. Funding recipients were identified by MSA, of which 83 (out of 366 in the United States) had funding activity. I compared this to the 582 successful Kickstarter technology entrepreneurship projects that represented 109 MSAs, as well as to the wider universe of 954 technology entrepreneurship projects that received any funding, no matter how small. These areas are mapped in Figure 2.

[Insert Figure 2 Here]

The final hypotheses, H5, also requires a comparison between venture capital selection and crowd selection, in this case as they relate to founding team gender. While female access to venture capital is a widespread concern (Coleman \& Robb, 2009; Harrison \& Mason, 2007; Klapper \& Parker, 2011; Miller, 2010), confounding factors have made empirical studies rare. Especially obscure has been the nature of selection biases. Without clear data, some scholars have argued that part of any biases might be due to the fact that women tend to seek VC less frequently and are less likely to be founders of technology companies (Coleman \& Robb, 2009; Harrison \& Mason, 2007; Klapper \& Parker, 2011). However, there is a strong presumption that decision-making in venture capital is biased against women, either because of homophily (over $80 \%$ of VC partners are male) or for other reasons (Coleman \& Robb, 2009; Holmquist \& Carter, 2009; Miller, 2010; Sorenson \& Stuart, 2005).

With data on the role of gender in selection itself is scarce, researchers have established statistics on the prevalence of female founders in venture-backed firms. Greene and Brush (2001) 
found that from 1987-1998, 3.5\% of VC backed firms had identifiable female founders, though gender was unclear in at least half of their sample, so the rate could be as high as $7 \%$. More recently, in a Dow Jones study of the 20,194 companies listed in VentureSource that received VC funding from 19972011, only 1.3\% were found to have a female founder (Canning et al., 2012). Thus, while it is not clear how much, if at all, gender biases the VC selection process, the outcome is that female founders are exceedingly rare.

\section{Results}

To examine the role of signals of quality, along with other determinants of successful crowdfunding, I conducted an analysis using logistic regression of the odds of successful funding. I controlled for the log of the goal of the project, project category, fundraising duration, reward levels, and whether the project was featured by Kickstarter on their home page. The results are in Table 3.

[Insert Table 3 Here]

To test H1, a demonstrated history of success, I examined whether projects that listed relevant past projects or employers by name are more likely to be selected than those that don't clearly indicate a relevant background. As can be seen in Model 2, explicit past evidence of success is predictive of successful funding. This finding holds for Model 6, which includes all potential signals.

For H2, I tested the role of endorsements on selection. Endorsements were explicit hyperlinks or quotes from outside organizations or new media providing support or legitimacy to projects. Most commonly, this was a quote from a journalist or prominent blog. Again, this hypothesis is supported 
by Models 3 and 6 as well, as outside endorsements significantly increase the chance of selection in crowdfunding.

The final signal of quality in $\mathrm{H} 3$ was preparation. Here, I looked at two measures: first, whether or not the project explicitly showed a prototype or early version of the product. Secondly, I examined whether pitches included a video. Kickstarter suggests that the key to demonstrating preparation is to include a video: "A video is by far the best way to get a feel for the emotions, motivations, and character of a project. It's a demonstration of effort and a good predictor of success." Again, both factors predicted selection in Model 4, Model 5, and Model 6, though the effects of proof of concept were weaker in the full model. This offers strong support for H3.

A key question about these findings is whether signals are important given other potential sources of information on entrepreneurs, such as social networks. While the role of social networks in securing venture capital funding has long been noted (Hsu, 2007; Shane \& Cable, 2002), such networks are of particular interest in crowdfunding. Individual networks are often harnessed to provide a supply of backers in from known acquaintances (Agrawal et al., 2010). This raises the concern that it is the direct network of individual entrepreneurs, rather than a more general group of investors, that is providing funding to crowdfunded projects. To test this concern, I ran the logistic regression on the subsample that included Facebook friends (FBF) of project founders. The results are in Table 4.

[Insert Table 4 Here]

I find that while social network size is a significant predictor of funding, signals of quality remain important. Again, I find strong support for H1, H2 and H3. For hypothesis H1, videos but 
not proofs of concepts appear significant in the combined model (Model 6), but both are important individually. Overall, these results suggest that while social networks help crowdfunding efforts, signals of quality are also used by potential investors.

H4 involves a comparison between the geographic outcomes of crowdfunding and venture capital funding. In order to calculate geographic concentration, I used the locational Gini coefficient (Krugman, 1992). The coefficient takes values greater than zero if the distribution of funded seed projects is more skewed than the overall population, with a 1 indicating complete concentration ${ }^{4}\left(\mathrm{Kim}_{\text {, }}\right.$ Barkley, \& Henry, 2002). Locational Gini was calculated in two ways. The first method, an absolute score, was based on an even distribution of populations across the 366 MSAs. The second method was a relative score, which compared concentration of funding to the 2010 census population figures per MSA. I used a jackknife approach to generate the standard errors.

[Insert Table 5 Here]

As can be seen in Table 5, locational Gini coefficients were smaller for crowdfunding, indicating less concentration than in the case of $\mathrm{VC}$ seed funding. Three of the four Gini coefficients for crowdfunding were significantly lower than that of VC. However, the difference between the relative locational Gini coefficient for crowdfunding of large (over $\$ 5,000$ ) projects was not significantly different than the Gini coefficient for VC funding. These results match visually with the maps in Figure 2, which show that while both crowdfunding and VC selection are clustered, they are not necessarily clustered in the same areas. The analysis of Gini coefficients offers partial support of H4:

\footnotetext{
${ }^{4}$ Some source divide the locational Gini in half, so that the maximum is .5
} 
crowdfunding does seem less concentrated than VC funding, though the difference is not great in magnitude.

[Insert Table 6]

[Insert Table 7]

Finally, I turn to H5, the role of gender in crowdfunding and venture capital in Tables 6 and 7. Among crowdfunded proposed projects, 142 were by women alone, 199 by mixed groups, and 1,560 by men alone (an additional 198 were not identifiable by gender). Female founders are thus present in $16.2 \%$ of proposed projects. Out of the 592 funded projects, 45 were from all-female teams, 80 from mixed gender teams, and 58 from teams not identifiable by gender, indicating that female founders were present in at least $21.1 \%$ of funded projects. This number is fifteen times higher than among VentureSource VC-backed companies. Further, gender was not predictive of selection under any specification, as can be seen in Table 7. These findings offer strong support for H5, that crowdfunding has less gender bias than VC selection.

Together, the results support H1, H2, and H3. Crowdfunding, despite being very different than VC funding, seems to respond to similar signals of quality. The data also supports, H4, though more ambiguously. Crowdfunding is less regionally concentrated, though not by a large margin. Finally, I found strong support for H5, crowdfunding appears to be less biased towards female entrepreneurs. 


\section{Discussion}

Prior to the development of crowdfunding, venture capitalists acted as the central institutions of technology entrepreneurship, as even alternative funding sources - such as angel investors or seed incubators - served as first step towards the eventual pursuit of venture capital. Crowdfunding differs in almost every respect from VC. Where VC is controlled by a few experts, crowdfunding relies on millions of individuals with uncertain backgrounds. Where VC sits in the center of a web of networks designed to identify and nurture startups (Ferrary \& Granovetter, 2009), crowdfunding operates independently of any existing institutional structure in entrepreneurship. And, where VC investment is rewarded with equity and monitoring rights, crowdfunding does not require equity participation, and offers no guaranteed rights to funders. Given this setting, it should not be surprising that critics have raised concerns that project quality may not be as clear or as influential to funders in crowdfunding settings, compared with more traditional investments (Bogost, 2012).

And yet, the findings suggest that the signals of quality that are used by VCs to assess the viability of new ventures are also used by crowdfunders. This bolsters the validity of these signals as indicators of startup potential, but also suggests that crowdfunding has the ability to distinguish quality potential projects from less promising ones. From this perspective, funders act like venture capitalists or other traditional sources of capital and evaluate the quality of the product, the team, and the likelihood of success (Gorman \& Sahlman, 1989; MacMillan, 1986). Since some projects are better than others, they receive funding, and lower-quality projects receive little to no backers. Though decisions are made individually, quality signals are further magnified through a Matthew Effect (Merton, 1957) that multiplies the impact of project quality. High quality projects attract backers 
who may promote the project to other potential backers, or external media, thus increasing the draw of the project.

Further, crowdfunding seems to avoid some of the biases that are pervasive in VC selection. Crowdfunding is more democratically distributed than VC funding. This is in part due to an easing of location-based restrictions on the extent of $\mathrm{VC}$ networks and monitoring abilities. It is also likely due to the fact that entrepreneurs can draw on backers from many locations using electronic communities and personal connections (Agrawal et al., 2010). Clustering still occurs, however, and the unequal distribution of high technology projects is not that different in magnitude than the inequality of VC-backed projects. This clustering does not appear to be related to differing selection criteria across different regions. In a separate regression (not shown), I tested whether the number of other Kickstarter projects in a region predicted success in fund raising, but found no significant effect. This suggests that the clustering may, instead, be due to the spread of Kickstarter across communities, since the crowdfunding approach is still quite novel.

More decisive were the results on gender biases in crowdfunding. The proportion of crowdfunded startups with female founders was larger by an order of magnitude than that of VCbacked firms. And, while there is little clear research on the ways in which gender bias occurs in the VC selection process, no bias was found in the analysis of crowdfunding success. Despite this, the proportion of crowdfunded companies with female cofounders was far less than the proportion of all firms in the US with female founders (Holmquist \& Carter, 2009). This may be due to the fact that women are more reluctant to seek particular sorts of funding, and are generally less prevent in high 
technology entrepreneurship (Harrison \& Mason, 2007); or it may be due to other forms of bias that were not readily detectable.

The fact that selection in crowdfunding looks to relevant quality figures while mitigating bias is important in the nascent movement to understand the role of institutional influence in entrepreneurship (Aldrich \& Fiol, 1994; Tolbert, David, \& Sine, 2011). VC investment plays many roles in high technology entrepreneurship. Once firms receive VC investment, they also receive help professionalizing and connections to vital resources (Baum \& Silverman, 2004; Hellmann \& Puri, 2002). Because of the many roles of venture capital, if VCs do not invest in a new firm, it can have far deeper consequences for startups than simply depriving them of a capital source. As Ferrary and Granovetter (2009) write: "By selecting start-ups, the VC firms implicitly prevent the other agents in the complex network of innovation from collaborating with start-ups that do not get VC funding. It could be argued that potential valuable innovations have never reached customers because they did not get VC funding to get connected to the network, but the data to evaluate this possibility would be difficult to acquire." The selections made by VCs have long-term implications for both winners and losers, and can shape the evolution of not just firms, but also the innovations they hope to bring to market.

Venture capital is thus both a critical part of the system of technology entrepreneurship and an important environmental factor in determining the outcomes of firms and innovations. The selection of some entrepreneurs (and the rejection of others) by venture capitalists can thus serve as a partial explanation of the success or failure of individual high technology entrepreneurial ventures, and 
even technological innovations as a whole. As Ferrary and Granovetter point out, however, this raises a potential problem about whether the institutionalized selection process is biased in a way that prevents some subset of valuable technologies and promising firms from achieving success. Many such biases inherent in the technology entrepreneurship system have been identified, as funding is inequitably distributed by age, region, and gender.

Scholars of entrepreneurship have two reasons to be concerned about the potential distorting role of VC selection in technology entrepreneurship. First, it raises endogeneity concerns about our understanding about technology entrepreneurship as separate from venture capital. Though studies have compared the development of technology entrepreneurship in different regions of the United States and internationally (Saxenian, 1996; Schoonhoven \& Eisenhardt, 2012), venture capital is generally considered to be an important part of the growth of high technology clusters in every context (Bresnahan \& Gambardella, 2004; Feldman, 2001). Thus, the study of technology entrepreneurship involves the examination of a system where $\mathrm{VC}$ selection mechanisms are endemic, so $\mathrm{VC}$ selection mechanisms are usually an irreducible part of the system of technology entrepreneurship itself. This problem is compounded by the fact that many datasets examining technology entrepreneurship draw mostly from populations of VC-backed firms, implicitly codifying the role of VC selection as a precondition of entrepreneurial success (Busenitz, Fiet, \& Moesel, 2004). Crowdfunding creates an alternative institutional condition with which to examine signals of quality and biases, and it suggests that while there is some universality to signals of quality, the biases seem to come from the institutional setting of $\mathrm{VC}$. 
In addition to illuminating the ways in which the $\mathrm{VC}$ selection mechanism may influence scholarly understanding of technology startups, an examination of the selection role of venture capital also allows us to shed light on a second issue: the role of institutional change in entrepreneurship. Scholars have increasingly been interested in the part that institutional contexts play on in the success of new ventures (Aldrich \& Fiol, 1994; Aldrich \& Martinez, 2007; Tolbert et al., 2011). Yet, as discussed, the institutional context supporting technology entrepreneurship has been remarkably stable itself, at least during the recent internet and computer booms in entrepreneurial innovation. Thus, there is little sense of how a radical shift in the institutional environment might affect the nature and type of technology entrepreneurship that develops, and the innovations that evolve as a result. Crowdfunding shows that even with radical changes in institutional context, there is substantial stability in the signals of project quality.

There are some limitations to these findings. One concern may be that crowdfunding and VC funding represent different funding contexts in many ways, though I make every effort to generate a sample of crowdfunded projects that look like the sorts of efforts VCs fund. While many of differences between VC and crowdfunding help establish the variance in environment that underlies the paper, they can also raise concerns about whether comparing crowdfunding to VC funding is an apples-toapples test. Most obviously, many of the crowdfunded projects are smaller than the smallest typical seen in VC seed funding, raising questions about whether crowdfunding, like venture capital, is being used by companies to start true ventures, rather than one-off projects. 
I attempted to address this concern in a number of ways. Empirically, I ran the tests of hypotheses 1-3 again with only the 287 projects seeking $\$ 50,000$ or more. All the results proved robust for these larger capital raises, though since proof-of-concepts and videos were nearly ubiquitous at that level of capital raise, those factors could not be properly accounted for. The gender effects also held with these larger projects, and female co-founders were better represented than in the VC samples (over $16 \%$ of projects had female founders). Similarly, using just the 122 projects with goals of $\$ 100,000$ or more resulted in the same findings. Since these numbers are closer to potential seed-level funding by VCs, they provide some comfort with the data.

Qualitatively, there seems to be strong intent among the projects in the sample to start ongoing entrepreneurial ventures. Of the 50 largest Kickstarter projects, 47 were projects in the technology entrepreneurship category. Of these, all 47 represented attempts to create ongoing firms ${ }^{5}$. Further, as the costs of starting a company drop, many industry sources cite Kickstarter as an important source of new innovations in technology and software in 2012 and 2013 (for examples, see Karabell, 2013; Lendino, 2013). Thus, even if crowdfunding represents a short-lived "bubble" in the funding of new ventures, as of the time of the analysis, it represented a viable alternative to venture capital.

There are other limitations besides the equivalence between crowdfunding and seed venture capital. The comparisons between crowdfunding and VC in terms of gender and geography are limited by the data on $\mathrm{VC}$ biases, which are less complete than might be desired, especially with regard to gender. The data I use is the best available, and there is no reason to doubt its validity, but better

\footnotetext{
${ }^{5}$ As of this writing, one company, Geode, has failed. The other 46 are still ongoing ventures.
} 
information on $\mathrm{VC}$ biases would be helpful. Additionally, while the paper examines the role of crowdfunding on VC biases, it does not attempt to identify the biases inherent in crowdfunding. Thus, while crowdfunding emolliates gender and geographic biases, it likely introduces other biases that are yet to be determined.

This paper makes three major contributions. First, it examines expert and crowd views of new ventures. My findings suggest that the two types of evaluators would use similar methods in determining the potential of an entrepreneurial venture, but they may do so with different biases and constraints. Secondly, the paper offers support for the validity of signals of quality in the entrepreneurship literature, as these quality signals hold true across contexts. Finally, this paper represents a first attempt to understand the crowdfunding phenomenon, and to put it in context with other sources of resources for technology entrepreneurs.

\section{Summary}

In his 2012 remarks upon signing the JOBS Act to legalize equity crowdfunding, President Obama stated that "for start-ups and small businesses, this bill is a potential game changer" (Obama, 2012). Crowdfunding does represent a major shift - a "game changer" - in the way that startups receive vital resources. This shift allows us to examine both the role of crowdfunding, and the role of VC, in making decisions about quality technology entrepreneurship. Crowdfunding backers and venture capitalists appear to be searching for the same signals of entrepreneurial potential, though they approach funding in diametrically different ways. Crowdfunding, however, seems to be less subject to gender and geographic biases than VC. 


\section{References}

Agrawal, A., Catalini, C., \& Goldfarb, A. (2010). The Geography of Crowdfunding. SSRN Electronic Journal. doi:10.2139/ssrn.1692661

Aldrich, H., \& Fiol, C. (1994). Fools rush in? The institutional context of industry creation. The Academy of Management Review.

Aldrich, H., \& Martinez, M. (2007). Many are called, but few are chosen: An evolutionary perspective for the study of entrepreneurship. Entrepreneurship: Theory and Practice, 41-57.

Amit, R., Brander, J., \& Zott, C. (1998). Why do venture capital firms exist? theory and canadian evidence. Journal of Business Venturing, 13(6), 441-466. doi:10.1016/S0883-9026(97)00061-X

Bagozzi, R., \& Dholakia, U. (2006). Open source software user communities: A study of participation in Linux user groups. Management Science, 52(7), 1099.

Baum, J., Calabrese, T., \& Silverman, B. (2000). Don't go it alone: Alliance network composition and startups' performance in Canadian biotechnology. Strategic management journal.

Baum, J., \& Oliver, C. (1996). Toward an institutional ecology of organizational founding. Academy of Management Journal.

Baum, J., \& Silverman, B. (2004). Picking winners or building them? Alliance, intellectual, and human capital as selection criteria in venture financing and performance of biotechnology startups. Journal of business venturing.

Beckman, C., Burton, M., \& O'Reilly, C. (2007). Early teams: The impact of team demography on VC financing and going public. Journal of Business Venturing.

Bogost, I. (2012, July). Kickstarter: Crowdfunding Platform Or Reality Show? Fast Company.

Boudreau, K., Lacetera, N., \& Lakhani, K. (2010). The Effects of Increasing Competition and Uncertainty on Incentives and Extreme-Value Outcomes in Innovation Contests. Harvard Business School ....

Brass, D. J., Galaskiewicz, J., Greve, H. R., Tsai, W. P., \& Anonymous. (2004). Taking stock of networks and organizations: A multilevel perspective. Academy of Management Journal, 47(6), 795-817.

Bresnahan, T., \& Gambardella, A. (2004). Building high-tech clusters: Silicon Valley and beyond.

Burtch, G., Ghose, A., \& Wattal, S. (2011). An Empirical Examination of the Antecedents and Consequences of Investment Patterns in Crowd-Funded Markets. SSRN Electronic Journal. doi:10.2139/ssrn.1928168

Busenitz, L., Fiet, J., \& Moesel, D. (2004). Signaling in Venture Capitalist-New Venture Team Funding Decisions: Does It Indicate Long-Term Venture Outcomes? Entrepreneurship Theory and Practice. 
Canning, J., Haque, M., \& Wang, Y. (2012). Women at the Wheel. New York.

Cardon, M. S., Sudek, R., \& Mitteness, C. (2009). THE IMPACT OF PERCEIVED ENTREPRENEURIAL PASSION ON ANGEL INVESTING, 29(2).

Chatterji, A. (2008). Spawned with a silver spoon. Strategic Management Journal.

Chen, H., Gompers, P., Kovner, A., \& Lerner, J. (2009). Buy Local ? The Geography of Successful and Unsuccessful Venture Capital Expansion.

Chen, M. (2008). Modeling a presidential prediction market. Management Science.

Chen, X., Yao, X., \& Kotha, S. (2009). Entrepreneurial Passion and Preparedness in Business Plan Presentations. Academy of Management Journal, 52(1), 199-214. doi:<span rwthpgen=" 1 " $>10.5465 /$ AMJ.2009. $</$ span $><$ strong $>36462018</$ strong $>$

Clay, A. (2012). Lessons in Authenticity from Makers, Pirates \& Occupiers: Guest Post. FMA.

Coleman, S., \& Robb, A. (2009). A comparison of new firm financing by gender: evidence from the Kauffman Firm Survey data. Small Business Economics.

Congress, 112th Jumpstart Our Business Startups Act (2012).

Delmar, F., \& Shane, S. (2003). Does business planning facilitate the development of new ventures? Strategic Management Journal.

Dushnitsky, G. (2009). Entrepreneurial Optimism in the Market for Technological Inventions. Organization Science, 21(1), 150-167. doi:10.1287/orsc.1090.0454

Dvorkin, E. (2013). Kickstarter-funded films headline Sundance. Kickstarter Blog. Retrieved February 5, 2013, from http://www.kickstarter.com/blog/kickstarter-funded-films-headline-sundance

Espositi, C. (2012). Crowdfunding Industry Report.

Evans, D., \& Leighton, L. (1989). Some empirical aspects of entrepreneurship. The American Economic Review.

Feldman, M. (2001). The entrepreneurial event revisited: firm formation in a regional context. Industrial and corporate change.

Ferrary, M., \& Granovetter, M. (2009). The role of venture capital firms in Silicon Valley's complex innovation network. Economy and Society.

Fiet, J. (1995). Reliance upon informants in the venture capital industry. Journal of Business Venturing.

Foo, M. Der, Wong, P. K., \& Ong, A. (2005). Do others think you have a viable business idea? Team diversity and judges' evaluation of ideas in a business plan competition. Journal of Business Venturing. 
Franke, N., \& Gruber, M. (2008). Venture Capitalists' Evaluations of Start-Up Teams: Trade-Offs, Knock-Out Criteria, and the Impact of VC Experience. ... Theory and Practice.

Fried, V., \& Hisrich, R. (1994). Toward a model of venture capital investment decision making. Financial management.

Gompers, P., \& Kovner, A. (2006). Skill vs. luck in entrepreneurship and venture capital: Evidence from serial entrepreneurs.

Gompers, P., \& Lerner, J. (2001). The venture capital revolution. Journal of Economic Perspectives.

Gompers, P., \& Lerner, J. (2004). The venture capital cycle.

Gorman, M., \& Sahlman, W. A. (1989). What do venture capitalists do? Journal of Business Venturing, 4(4), 231-248. doi:10.1016/0883-9026(89)90014-1

Greene, P., \& Brush, C. (2001). Patterns of venture capital funding: is gender a factor? Venture Capital: An .... doi:10.1080/13691060010024737

Greene, P., \& Hart, M. (2003). Women entrepreneurs: Moving front and center: An overview of research and theory. USASBE White Papers ....

Harrison, R., \& Mason, C. (2007). Does gender matter? Women business angels and the supply of entrepreneurial finance. Entrepreneurship Theory and ..., 445-472.

Hellmann, T., \& Puri, M. (2002). Venture Capital and the Professionalization of Start-up Firms: Empirical Evidence. The Journal of Finance.

Higgins, M. J., Stephan, P. E., \& Thursby, J. G. (2011). Conveying quality and value in emerging industries: Star scientists and the role of signals in biotechnology. Research Policy, 40(4), 605-617.

Hisrich, R. D., \& Jankowicz, A. D. (1990). Intuition in venture capital decisions: An exploratory study using a new technique. Journal of Business Venturing, 5(1), 49-62. doi:10.1016/0883-9026(90)90026-P

Holmquist, C., \& Carter, S. L. (2009). The Diana project: pioneering women studying pioneering women. Small Business Economics, 32(2), 121-128.

Honig, B., \& Karlsson, T. (2004). Institutional forces and the written business plan. Journal of Management.

Hsu, D. (2004). What do entrepreneurs pay for venture capital affiliation? The Journal of Finance.

Hsu, D. (2007). Experienced entrepreneurial founders, organizational capital, and venture capital funding. Research Policy.

Jeanty, P. (2010). NEARSTAT: Stata module to calculate distance-based variables and export distance matrix to text file. Boston College Working Papers in Economics. 
Jeffries, A. (2013). How Kickstarter stole CES: the rise of the indie hardware developer. The Verge. Retrieved January 12, 2013, from http://www.theverge.com/2013/1/10/3861406/kickstarter-at-ces

Jeppesen, L. B., \& Frederiksen, L. (2006). Why do users contribute to firm-hosted user communities? The case of computer-controlled music instruments. Organization Science, 17(1), 45.

Karabell, Z. (2013). The Kickstarter Economy: How Technology Turns Us All Into Bankers. Atlantic Monthly.

Kenney, M., \& Burg, U. Von. (1999). Technology, entrepreneurship and path dependence: industrial clustering in Silicon Valley and Route 128. Industrial and corporate change.

Kim, Y., Barkley, D., \& Henry, M. (2002). Industry characteristics linked to establishment concentrations in nonmetropolitan areas. Journal of Regional Science.

Kirsch, D., Goldfarb, B., \& Gera, A. (2009). Form or substance: The role of business plans in venture capital decision making. Strategic Management Journal.

Klapper, L., \& Parker, S. (2011). Gender and the business environment for new firm creation. The World Bank Research Observer.

Kortum, S., \& Lerner, J. (2000). Assessing the contribution of venture capital to innovation. RAND Journal of Economics.

Krugman, P. (1992). Geography and trade.

Kuppuswamy, V., \& Bayus, B. L. (2013). CROWDFUNDING CREATIVE IDEAS: THE DYNAMICS OF PROJECT BACKERS IN KICKSTARTER.

Lee, G. K., \& Cole, R. E. (2003). From a firm-based to a community-based model of knowledge creation: The case of the Linux kernel development. Organization Science, 633-649.

Lendino, J. (2013, January). The 8 Biggest Trends at CES 2013. PC Magazine.

Lerner, J. (2002). Boom and bust in the venture capital industry and the impact on innovation.

Lerner, J. (2012). Venture capitalists and the oversight of private firms. The Journal of Finance.

MacMillan, I. (1986). Criteria used by venture capitalists to evaluate new venture proposals. Journal of Business venturing.

Mannes, A. E. (2009). Are We Wise About the Wisdom of Crowds? The Use of Group Judgments in Belief Revision. Management Science, 55(8), 1267-1279. doi:10.1287/mnsc.1090.1031

Merton, R. (1957). Priorities in scientific discovery: a chapter in the sociology of science. American sociological review.

Michael, S. (1974). Market Signaling: informational transfer in hiring und related screening process. 
Miller, C. (2010). Why So Few Women in Silicon Valley? New York Times.

Mollick, E. (2005). Tapping into the underground. MIT Sloan management review, 46(4), 21.

Mollick, E. (2012). People and Process, Suits and Innovators: The Role of Individuals in Firm Performance. Strategic Management Journal.

Mollick, E. (2013). The Dynamics of Crowdfunding: Determinants of Success and Failure. SSRN Electronic Journal. doi:10.2139/ssrn.2088298

Morduch, J. (1999). The Microfinance Promise. Journal of Economic Literature.

Munoz, S., \& Bangdiwala, S. (1997). Interpretation of Kappa and B statistics measures of agreement. Journal of Applied Statistics.

Obama, B. (2012). Remarks by the President at JOBS Act Bill Signing.

Owen-Smith, J., \& Powell, W. (2004). Knowledge networks as channels and conduits: the effects of spillovers in the Boston .... Organization Science.

Ozmeck, A., \& Miles, D. (2011). Stata utilities for geocoding and generating travel time and travel distance information. Stata Journal.

O'Mahony, S. (2003). Guarding the commons: how community managed software projects protect their work. Research Policy, 32(7), 1179-1198.

Phillips, D. (2002). A Genealogical Approach to Organizational Life Chances: The Parent-Progeny Transfer. Administrative Science Quarterly.

Poetz, M., \& Schreier, M. (2012). The value of crowdsourcing: can users really compete with professionals in generating new product ideas? Journal of Product Innovation Managment, 29(2).

Ray, R. (2006). Prediction Markets and the Financial" Wisdom of Crowds”. The Journal of Behavioral Finance.

Ruef, M., Aldrich, H., \& Carter, N. (2003). The structure of founding teams: Homophily, strong ties, and isolation among US entrepreneurs. American Sociological Review.

Saxenian, A. (1996). Regional Advantage: Culture and Competition in Silicon Valley and Route 128 (p. 226). Harvard University Press.

Schoonhoven, C., \& Eisenhardt, K. (2012). Regions as Industrial Incubators of Technology-based Ventures. In E. S. Mills \& J. F. McDonald (Eds.), Sources of Metropolitan Growth (p. 334). Transaction Publishers.

Schumpeter, J. (1942). Capitalism, Socialism and Democracy. Economica (Vol. 11, p. 40). Harper. doi:10.2307/2549943 
Schwienbacher, A., \& Larralde, B. (2010). Crowdfunding of Small Entrepreneurial Ventures. SSRN Electronic Journal. doi:10.2139/ssrn.1699183

Shane, S., \& Cable, D. (2002). Network ties, reputation, and the financing of new ventures. Management Science.

Shane, S., \& Venkataraman, S. (2003). Guest editors' introduction to the special issue on technology entrepreneurship. Research Policy, 32(2), 181-184. doi:10.1016/S0048-7333(02)00104-X

Shepherd, D. (1999). Venture capitalists' assessment of new venture survival. Management Science.

Sorenson, O., \& Stuart, T. (2005). The evolution of venture capital investment networks. Federal Reserve Bank of Atlanta.

Stuart, T., Hoang, H., \& Hybels, R. (1999). Interorganizational endorsements and the performance of entrepreneurial ventures. Administrative science quarterly.

Stuart, T., \& Shane, S. (2002). Organizational endowments and the performance of university start-ups. Management Science.

Stuart, T., \& Sorenson, O. (2003a). Liquidity events and the geographic distribution of entrepreneurial activity. Administrative Science Quarterly.

Stuart, T., \& Sorenson, O. (2003b). The geography of opportunity: spatial heterogeneity in founding rates and the performance of biotechnology firms. Research Policy.

Stuart, T., \& Sorenson, O. (2005). Social networks and entrepreneurship. Handbook of entrepreneurship research.

Stuart, T., \& Sorenson, O. (2008). Strategic networks and entrepreneurial ventures. Strategic Entrepreneurship Journal.

Sørensen, J., Burton, M., \& Beckman, C. (2002). Coming from good stock: Career histories and new venture formation. Social Structure and Organization Revisited (pp. 229-262). Elsevier Science.

Sørensen, J., \& Fassiotto, M. (2011). Organizations as fonts of entrepreneurship. Organization Science, 22(5), 1322-1331.

Terwiesch, C., \& Ulrich, K. (2009). Innovation tournaments: Creating and selecting exceptional opportunities.

Tolbert, P., David, R., \& Sine, W. (2011). Studying choice and change: The intersection of institutional theory and entrepreneurship research. Organization Science.

Ueda, M. (2004). Banks versus venture capital: Project evaluation, screening, and expropriation. The Journal of Finance.

Williams, A., \& KOMISAR, R. (2005). Wheels and deals in Silicon Valley. New York Times. 
Figure 1: Example Kickstarter page

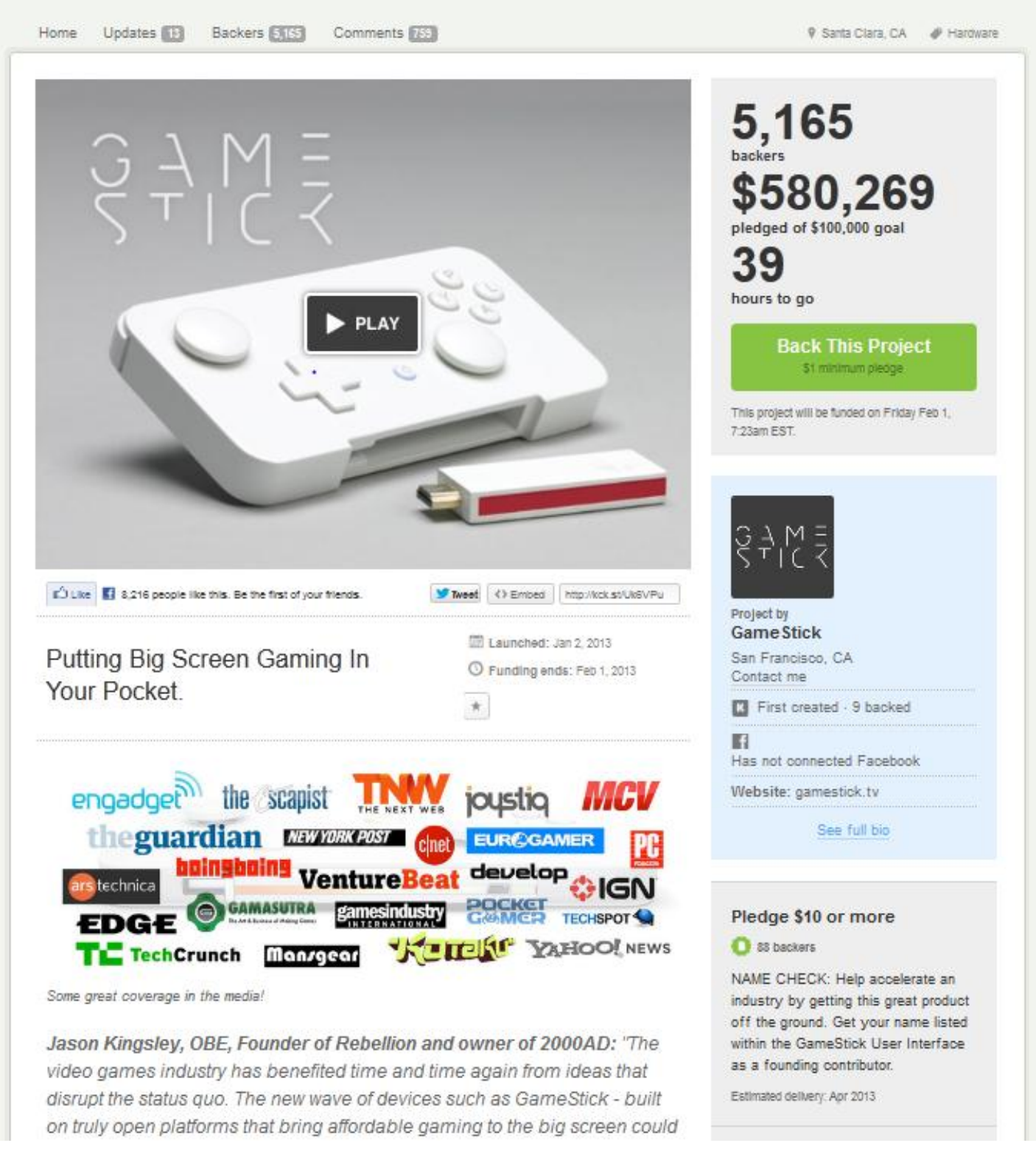


Figure 2 Distribution of Funding

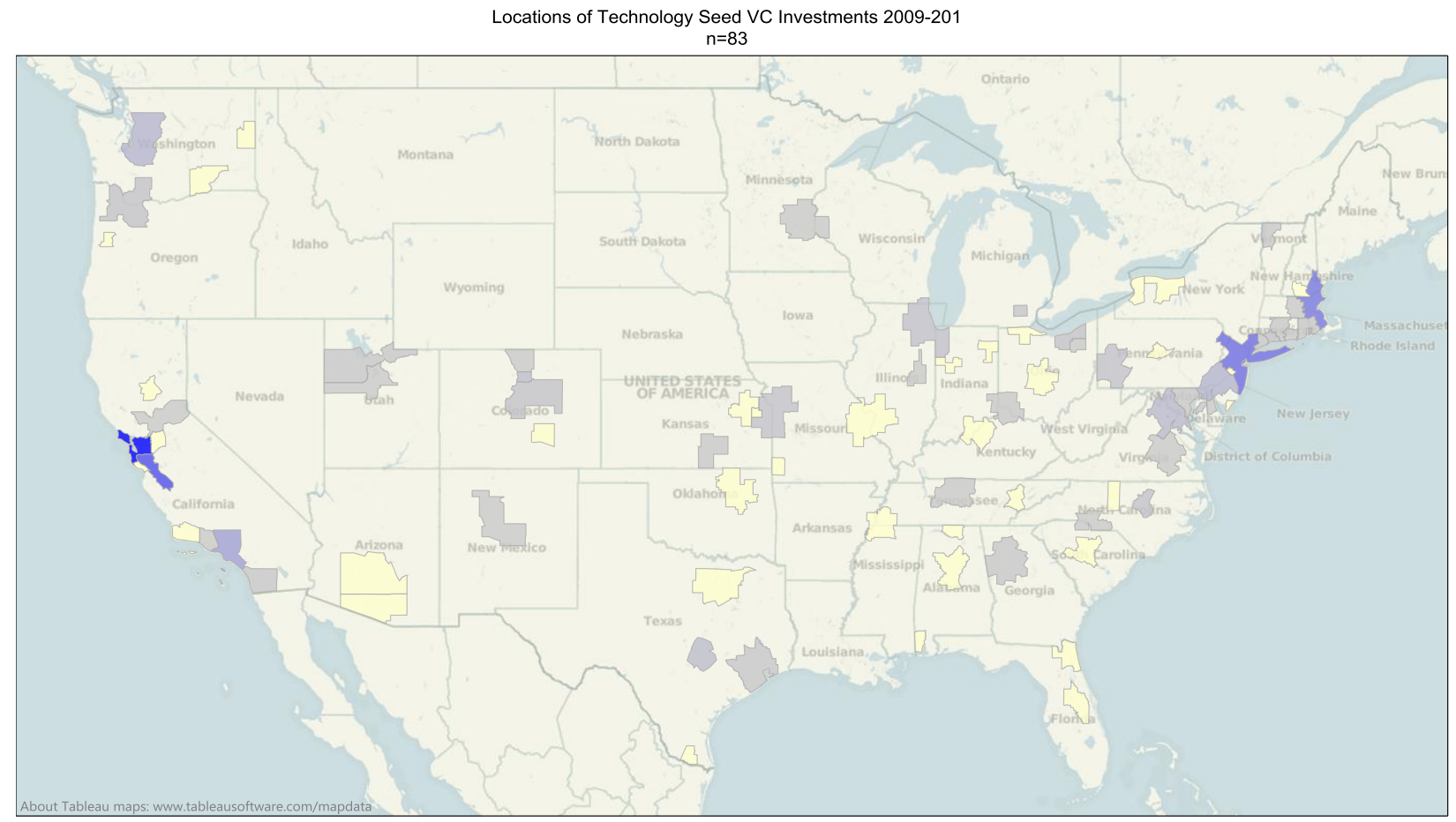

Map based on closest MSA. Color shows number of deals. Pale yellow areas have only one deal. Biotechnology ventures not included

Deals

$1.0 \quad 188.0$

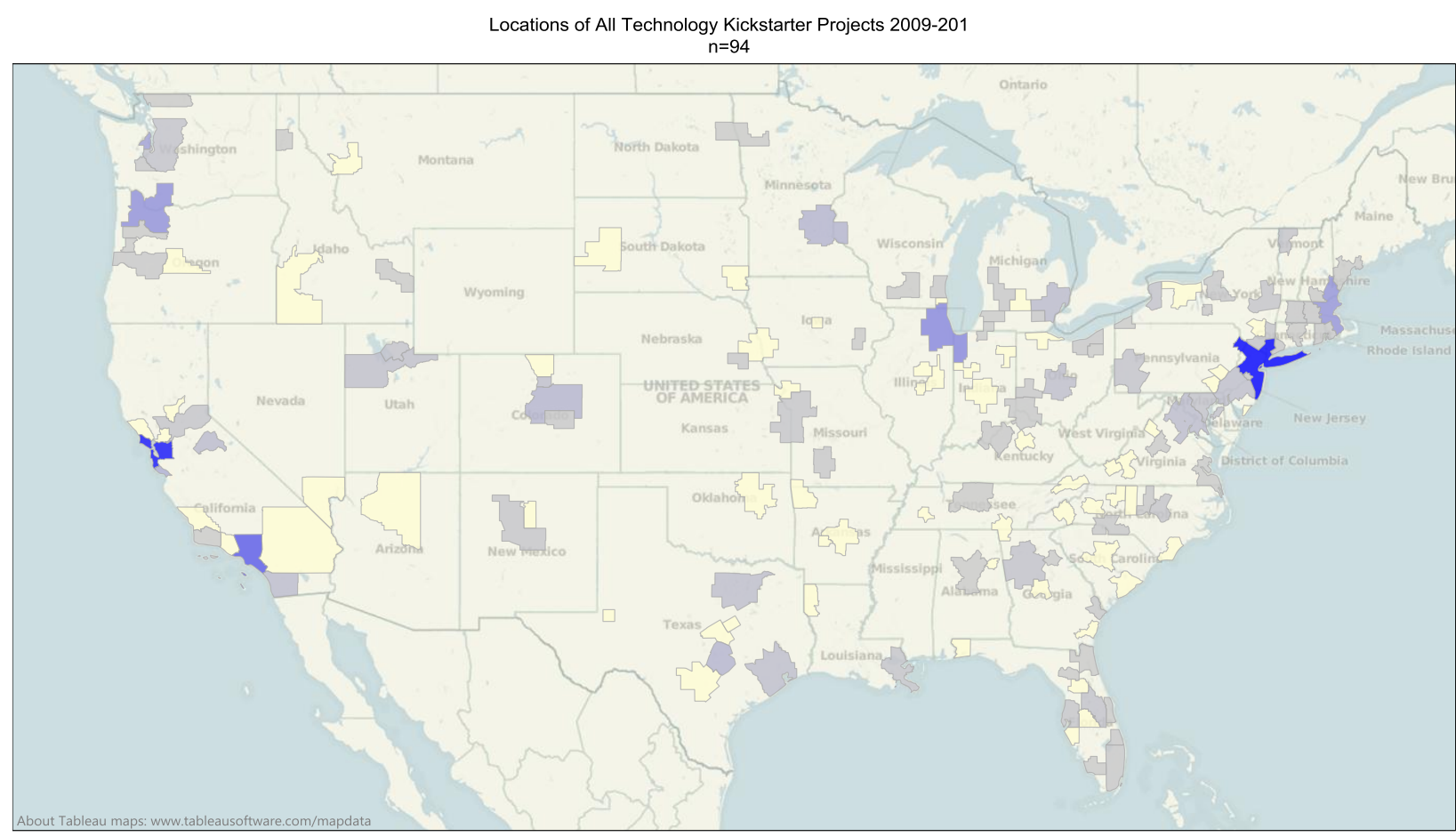

Map based on closest MSA. Color shows number of projects. Pale yellow areas have only one project

Deals

$1.0 \quad 115.0$ 
Table 1: Summary of Data

\begin{tabular}{|c|c|c|c|c|}
\hline VARIABLES & $\begin{array}{l}(1) \\
\text { All } \\
\end{array}$ & $\begin{array}{c}(2) \\
\text { Selected }\end{array}$ & $\begin{array}{c}(3) \\
\text { All FB }\end{array}$ & $\begin{array}{c}(4) \\
\text { Selected FB }\end{array}$ \\
\hline Selected & $\begin{array}{c}0.288 \\
(0.453)\end{array}$ & & $\begin{array}{c}0.309 \\
(0.462)\end{array}$ & \\
\hline \$ Goal & $\begin{array}{c}31,556 \\
(64,302)\end{array}$ & $\begin{array}{c}26,832 \\
(63,399)\end{array}$ & $\begin{array}{c}32,366 \\
(60,337)\end{array}$ & $\begin{array}{c}23,401 \\
(32,381)\end{array}$ \\
\hline$\%$ Funded & $\begin{array}{c}1.000 \\
(3.741)\end{array}$ & $\begin{array}{c}3.240 \\
(6.453)\end{array}$ & $\begin{array}{c}1.110 \\
(4.318)\end{array}$ & $\begin{array}{c}3.373 \\
(7.275)\end{array}$ \\
\hline totalbackers & $\begin{array}{c}371.0 \\
(2,458)\end{array}$ & $\begin{array}{c}1,208 \\
(4,477)\end{array}$ & $\begin{array}{c}364.0 \\
(2,484)\end{array}$ & $\begin{array}{c}1,101 \\
(4,381)\end{array}$ \\
\hline Rewards & $\begin{array}{c}8.377 \\
(3.799)\end{array}$ & $\begin{array}{c}9.924 \\
(4.547)\end{array}$ & $\begin{array}{c}8.827 \\
(3.855)\end{array}$ & $\begin{array}{c}10.37 \\
(4.534)\end{array}$ \\
\hline Featured & $\begin{array}{c}0.0531 \\
(0.224)\end{array}$ & $\begin{array}{c}0.163 \\
(0.369)\end{array}$ & $\begin{array}{c}0.0594 \\
(0.236)\end{array}$ & $\begin{array}{c}0.162 \\
(0.369)\end{array}$ \\
\hline Duration & $\begin{array}{c}40.25 \\
(14.66)\end{array}$ & $\begin{array}{c}39.40 \\
(13.22)\end{array}$ & $\begin{array}{c}38.73 \\
(13.11)\end{array}$ & $\begin{array}{c}38.78 \\
(12.40)\end{array}$ \\
\hline Endorsed & $\begin{array}{c}0.215 \\
(0.411)\end{array}$ & $\begin{array}{c}0.381 \\
(0.486)\end{array}$ & $\begin{array}{c}0.244 \\
(0.430)\end{array}$ & $\begin{array}{c}0.414 \\
(0.493)\end{array}$ \\
\hline Proof of Concept & $\begin{array}{c}0.954 \\
(0.209)\end{array}$ & $\begin{array}{c}0.988 \\
(0.108)\end{array}$ & $\begin{array}{c}0.956 \\
(0.205)\end{array}$ & $\begin{array}{c}0.990 \\
(0.100)\end{array}$ \\
\hline Past Evidence & $\begin{array}{c}0.402 \\
(0.490)\end{array}$ & $\begin{array}{c}0.515 \\
(0.500)\end{array}$ & $\begin{array}{c}0.415 \\
(0.493)\end{array}$ & $\begin{array}{c}0.478 \\
(0.500)\end{array}$ \\
\hline $\mathrm{FBF}$ & & & $\begin{array}{c}447.9 \\
(569.0)\end{array}$ & $\begin{array}{c}497.0 \\
(561.0)\end{array}$ \\
\hline Observations & 2,052 & 590 & 960 & 297 \\
\hline
\end{tabular}


Table 2: Correlation Table

\begin{tabular}{|c|c|c|c|c|c|c|c|c|c|}
\hline & Select & \$ Goal & Fund & Backers & Reward & Feat. & Duration & Endrse & Proof \\
\hline Selected & 1 & & & & & & & & \\
\hline \$ Goal & -0.047 & 1 & & & & & & & \\
\hline Fund & 0.381 & -0.015 & 1 & & & & & & \\
\hline Backers & 0.216 & 0.331 & 0.58 & 1 & & & & & \\
\hline Rewards & 0.258 & 0.181 & 0.077 & 0.146 & 1 & & & & \\
\hline Featured & 0.311 & 0.018 & 0.319 & 0.238 & 0.043 & 1 & & & \\
\hline Duration & -0.037 & -0.016 & -0.004 & -0.025 & -0.065 & 0.04 & 1 & & \\
\hline Endorse & 0.218 & 0.049 & 0.175 & 0.146 & 0.143 & 0.031 & -0.024 & 1 & \\
\hline Proof & 0.161 & 0.018 & 0.083 & 0.052 & 0.134 & 0.06 & -0.076 & 0.102 & 1 \\
\hline Past Evidence & 0.099 & 0.106 & 0.057 & 0.103 & 0.079 & 0.069 & -0.046 & 0.106 & 0.07 \\
\hline
\end{tabular}


Table 3: Logits for Funding

\begin{tabular}{|c|c|c|c|c|c|c|}
\hline VARIABLES & $\begin{array}{c}(1) \\
\text { Model } 1\end{array}$ & $\begin{array}{c}(2) \\
\text { Model } 2\end{array}$ & $\begin{array}{c}(3) \\
\text { Model } 3\end{array}$ & $\begin{array}{c}(4) \\
\text { Model } 4\end{array}$ & $\begin{array}{c}(5) \\
\text { Model } 5\end{array}$ & $\begin{array}{c}(6) \\
\text { Model } 6\end{array}$ \\
\hline Log(Goal) & $\begin{array}{c}0.35^{* * *} \\
(0.052)\end{array}$ & $\begin{array}{c}0.32 * * * \\
(0.048)\end{array}$ & $\begin{array}{c}0.28 * * * \\
(0.045)\end{array}$ & $\begin{array}{c}0.34 * * * \\
(0.051)\end{array}$ & $\begin{array}{c}0.32 * * * \\
(0.048)\end{array}$ & $\begin{array}{c}0.25^{* * *} \\
(0.040)\end{array}$ \\
\hline Duration & $\begin{array}{c}0.99 * \\
(0.004)\end{array}$ & $\begin{array}{c}0.99 * \\
(0.004)\end{array}$ & $\begin{array}{c}0.99 * \\
(0.004)\end{array}$ & $\begin{array}{c}0.99 * \\
(0.004)\end{array}$ & $\begin{array}{c}0.99 * \\
(0.004)\end{array}$ & $\begin{array}{c}0.99 \\
(0.004)\end{array}$ \\
\hline Featured & $\begin{array}{c}27.36 * * * \\
(8.501)\end{array}$ & $\begin{array}{c}25.51 * * * \\
(7.956)\end{array}$ & $\begin{array}{c}25.40 * * * \\
(8.005)\end{array}$ & $\begin{array}{c}26.84 * * * \\
(8.423)\end{array}$ & $\begin{array}{c}27.06 * * * \\
(8.600)\end{array}$ & $\begin{array}{c}23.82 * * * \\
(7.619)\end{array}$ \\
\hline Rewards & $\begin{array}{l}1.22 * * * \\
(0.020)\end{array}$ & $\begin{array}{c}1.22 * * * \\
(0.020)\end{array}$ & $\begin{array}{l}1.21 * * * \\
(0.020)\end{array}$ & $\begin{array}{l}1.22 * * * \\
(0.020)\end{array}$ & $\begin{array}{l}1.21 * * * \\
(0.020)\end{array}$ & $\begin{array}{l}1.20 * * * \\
(0.020)\end{array}$ \\
\hline Past Evidence & & $\begin{array}{l}1.98 * * * \\
(0.224)\end{array}$ & & & & $\begin{array}{l}1.64 * * * \\
(0.195)\end{array}$ \\
\hline Endorsed & & & $\begin{array}{c}3.35 * * * \\
(0.431)\end{array}$ & & & $\begin{array}{c}2.81 * * * \\
(0.373)\end{array}$ \\
\hline Proof of Concept & & & & $\begin{array}{c}4.04 * * * \\
(1.659)\end{array}$ & & $\begin{array}{c}2.30 * \\
(0.983)\end{array}$ \\
\hline Video & & & & & $\begin{array}{c}6.04 * * * \\
(1.825)\end{array}$ & $\begin{array}{c}5.31 * * * \\
(1.654)\end{array}$ \\
\hline Category Controls & YES & YES & YES & YES & YES & YES \\
\hline Constant & $\begin{array}{c}9.63 * * * \\
(6.038)\end{array}$ & $\begin{array}{c}11.18 * * * \\
(7.089)\end{array}$ & $\begin{array}{c}17.28 * * * \\
(11.278)\end{array}$ & $\begin{array}{c}2.61 \\
(1.936)\end{array}$ & $\begin{array}{c}2.74 \\
(1.861)\end{array}$ & $\begin{array}{c}2.52 \\
(2.028)\end{array}$ \\
\hline Observations & 2,052 & 2,052 & 2,052 & 2,052 & 2,052 & 2,052 \\
\hline chi2 & 418.13 & 454.51 & 505.79 & 434.10 & 471.20 & 573.94 \\
\hline $\mathrm{p}$ & 0.00 & 0.00 & 0.00 & 0.00 & 0.00 & 0.00 \\
\hline Pseudo $\mathrm{R}^{2}$ & 0.17 & 0.18 & 0.21 & 0.18 & 0.19 & 0.23 \\
\hline
\end{tabular}

Exponentiated Form

$\mathrm{SE}$ in parentheses

$* * * \mathrm{p}<0.01, * * \mathrm{p}<0.05, * \mathrm{p}<0.1$ 
Table 4: Logits for Funding Including Social Networks

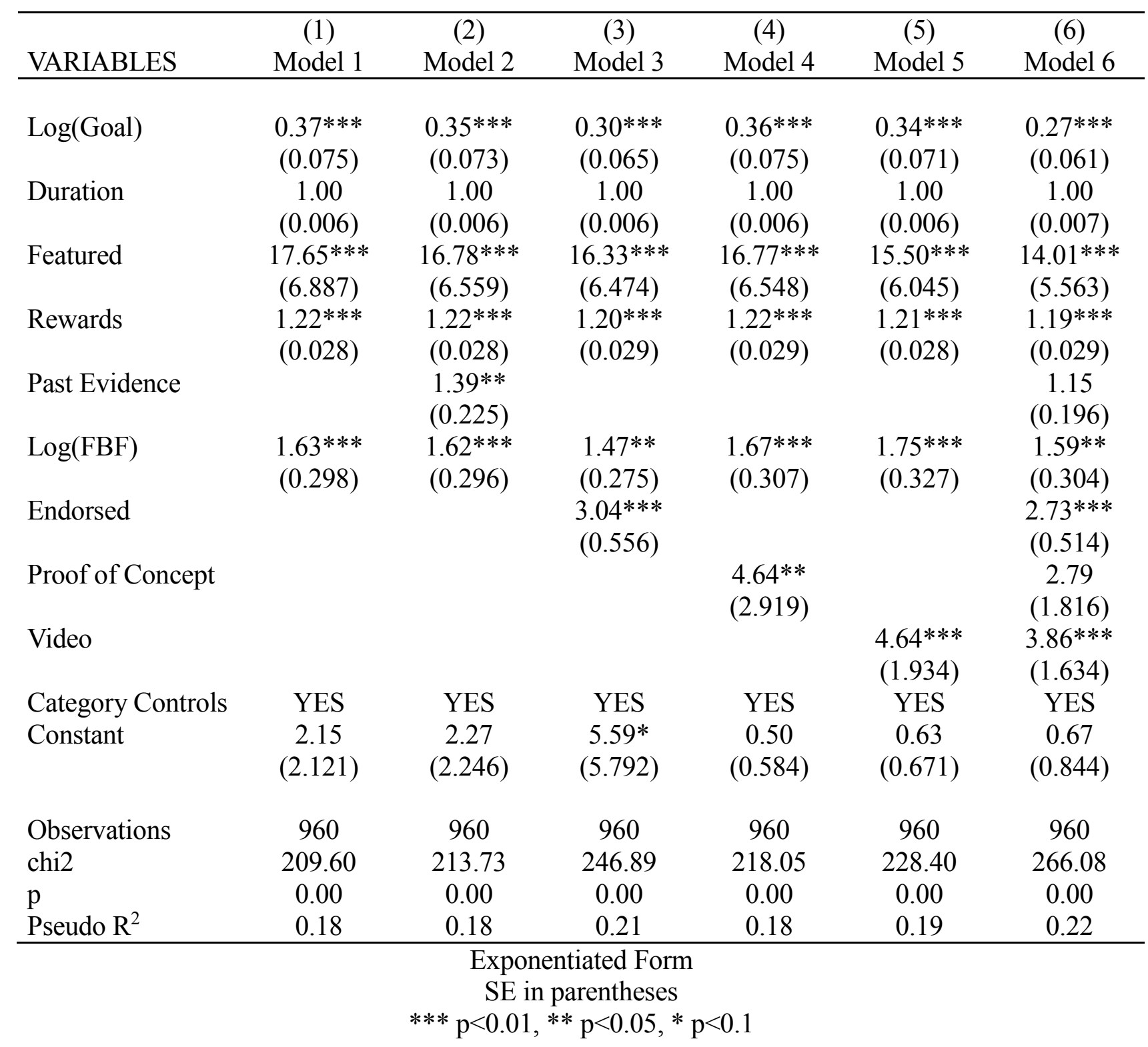


Table 5: Locational Gini Coefficients

\begin{tabular}{|c|c|c|c|}
\hline & $\begin{array}{c}(1) \\
\text { Seed VC } \\
\end{array}$ & $\begin{array}{c}(2) \\
\text { Seed Crowd } \\
\end{array}$ & $\begin{array}{c}(3) \\
\text { All Crowd } \\
\end{array}$ \\
\hline Relative & $\begin{array}{c}.915 \\
(.012)\end{array}$ & $\begin{array}{c}.878 \\
(.023)\end{array}$ & $\begin{array}{l}.810^{\dagger} \\
(.024)\end{array}$ \\
\hline Absolute & $\begin{array}{l}.953 \\
(.012)\end{array}$ & $\begin{array}{l}.905^{\dagger} \\
(.015)\end{array}$ & $\begin{array}{l}871^{\dagger} \\
(.019)\end{array}$ \\
\hline Observations & 366 & 366 & 366 \\
\hline
\end{tabular}

${ }^{\dagger}$ Significantly different from Seed VC at $p<.01$ 
Table 5: Gender among Seed Companies Receiving Funding

\begin{tabular}{lccc}
\hline & $(1)$ & $(2)$ & $(3)$ \\
& VC & VC & Crowd \\
& (Canning et al., 2012) & (Greene \& Brush, 2001) & \\
\hline \multirow{2}{*}{ Female } & .013 & .067 & $.211^{\dagger}$ \\
& $(.000)$ & $(.004)$ & $(.017)$ \\
& & & \\
\hline Observations & 20194 & 4034 & 592 \\
\hline
\end{tabular}

$\dagger$ Significantly different from both $\mathrm{VC}$ rates at $\mathrm{p}<.01$

Greene and Brush data excludes individuals of unknown gender, Crowd includes them as nonfemale. 
Table 6: Crowdfunding Selection by Gender

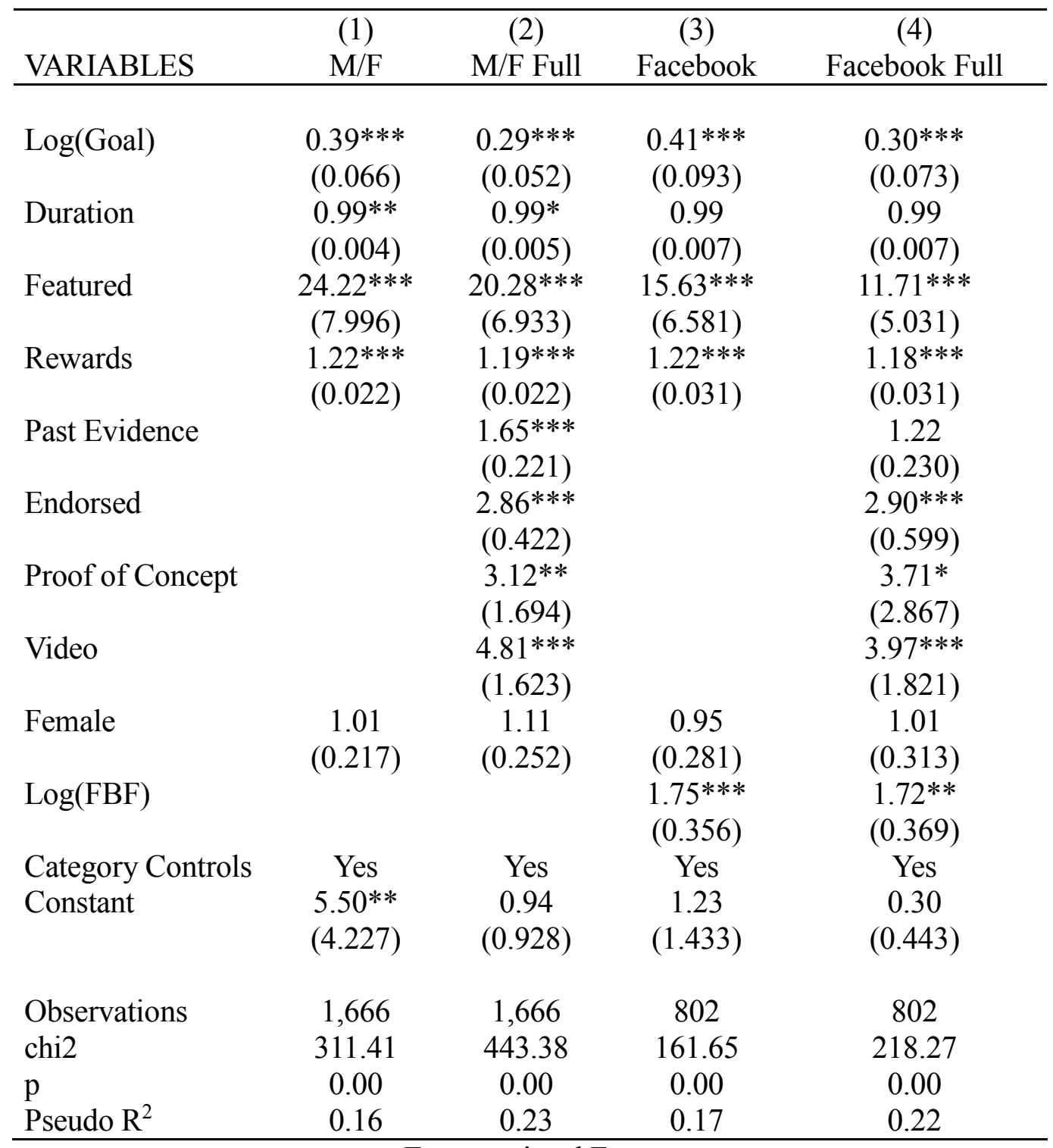

Exponentiated Form

$\mathrm{SE}$ in parentheses

$* * * \mathrm{p}<0.01, * * \mathrm{p}<0.05, * \mathrm{p}<0.1$ 